\title{
Towards business ecosystems for connected health
}

\author{
Julius Francis Gomes, M.Sc ${ }^{1}$; Minna Pikkarainen, D.Sc ${ }^{1}$; Petri Ahokangas, D.Sc ${ }^{1}$; Riikka Niemelä, MH.Sc ${ }^{2}$
}

${ }^{1}$ Martti Ahtisaari Institute of Global Business and Economics, Oulu Business School, University of Oulu, Finland; ${ }^{2}$ Research Unit of Medical Imaging, Physics, and Technology, University of Oulu, Finland

Julius Francis Gomes, Martti Ahtisaari Institute of Global Business and Economics, University of Oulu, FI-90014 University of Oulu, FINLAND. Email: julius.francisgomes@oulu.fi

\begin{abstract}
Digitalisation is seen as a vehicle for restructuring practices of social and health care in Finland. A conceptual model of connected health has evolved over time focusing on bringing together individuals and health professionals by means of 'eHealth', 'telecare', 'telemedicine' or 'telehealth' services and data connected via the Internet of Things. Digital transformation has triggered the emergence of innovative connected health services, as well as novel business models in the health and healthcare sector. Additionally, current literature emphasises growing importance of ecosystems in advancing the connected health business. The main reason for this, the increased understanding of business ecosystems would allow companies to create coherent services that would be easier for patients and health professionals (e.g. doctors and nurses) to use.
\end{abstract}

This paper aims to develop and present a conceptual model for business ecosystem for connected health by mapping service needs for healthcare in the future. For this research, we conducted 16 meetings/workshops related to business models and business ecosystems. We also involved different end-user groups in our research (seven doctor interviews, four workshops with nurses and digital discussions and workshops with 12 parents with sick children).

This qualitative case study illustrates the construct of the Nordic Central Hospital test lab-an innovation ecosystem for connected health service providers. Alongside the broad service map, we demonstrate the logic of value flow between different layers of services in the ecosystem. From an originality perspective, this multidisciplinary paper focuses on the pediatric day surgery to check the scope of connected health, which has not been done before.

Keywords: connected health, business ecosystems, innovation ecosystems, business model, internet of things

\section{Introduction}

The preparation for the restructuring of social and health care is advancing quite rapidly in Finland. Häyrinen [1] marks the overall transformation to be a change of practices by means of digitalisation, which is supported by the general population's technological literacy, intent to adapt easier and better alternatives compared to conventional solutions, and by the growing health tech industry's positive promotion. Services such as Kanta and Kelain are technologically ready [2] and many more disruptive healthcare services are on the way.

Since the birth of the Internet, a lot of " $\mathrm{e}$ "-terms have started to appear in the media and in literature [3]. 
Such terms include email, ecommerce and also eHealth "eHealth" as a term was first coined in 2000 and has lived up to most of its promises [4]. A certain pattern can be observed in the healthcare sector parallel with the development of information and communication technologies. Considering this pattern and the recent advancements in the development of communication networks (such as 5G) [5], it is important to analyse how the healthcare sector and the business ecosystems within could evolve in the future.

Additionally, the recent growth of sensor-based technologies has made the availability and transmission of mass scale data more accessible. The Internet of Things (IoT) is one of the biggest enablers for such advancement for a connected society. Martikainen et al. [6] marked increasing interest of different stakeholders in healthcare IT systems development in a recent period. For a connected society where health information will be more easily accessible and usable in healthcare, "connected health" is a term that is being jargoned recently [7]. Connected health as a terminology can be easily confused with "connected healthcare" due to diction similarity. However, while connected healthcare is a model for healthcare delivery that uses technology, connected health allows availing proper information at proper hands at the proper time according to the UCD Connected Health Research Unit [8]. Connected health is often referred to as a model for health/ lifestyle management, with the surge of healthcare services like MyData, Kanta and Kelain data from connected health sources all being useful in healthcare. We consider that these two terms are converging and becoming interchangeable in the future [9].

Galbraith et al. [10] state that 'connected health' is a more recent term which replaces or is used interchangeably with 'eHealth', 'telecare', 'telemedicine' or 'telehealth'. Complementing this notion, we refer to John Iglehart [7], where he marks connected health to be an umbrella term combining multiple tech-aided health service concepts. The point is, connected health is not only about eHealth, mHealth, telecare, telemedicine or telehealth as an isolated service type. Combining all of this and harnessing the potential of sensorbased data collection using IoT devices and Al-aided data analytics, connected health offers a new dimension of healthcare service delivery.

Caulfield \& Donnelly [11] provides one of the most comprehensive definitions of connected health, where it is marked to encompass such terms as wireless, digital, electronic, mobile and telehealth. They also mention that connected health refers to a conceptual health management model where devices, services or interventions are designed around patients' needs, and health related data is disseminated in a way that patients can receive care in the most proactive and efficient manner.

A conceptual model of connected health has evolved over time with particular focus on connecting patients and the health professionals by means of 'eHealth', 'telecare', 'telemedicine' or 'telehealth services and data connected via the Internet of Things (IoT). The IoT can be characterised in connected health as dealing with billions of connected 'things' such as sensors or devices to enhance healthcare decision making. Building the connected health model focused on patients' needs and efficient use of patient data through digital analytics promises results that is more efficient.

Pitkänen \& Pitkäranta [12] identify digitalised workflows of healthcare professionals as enablers of improvement in the healthcare services of the future. Pang et al. [13] and Gomes \& Moqaddamerad [14] point out the necessity and potential of ecosystemic business development in the futures healthcare sector, which will be highly aided by tech.

In the Finnish healthcare sector, we observe a significant number of health/ wellness/healthcare service startups and SMEs, alongside numbers of bigger corporations. Gomes \& Moqaddemerad [14] stated that there is an increasing number of private players in the healthcare-related business sector who are interested in the revenue streams as well as the service provisioning objectives of the sector. In our attempt to delve into this sector, we use the concept of business models as a boundary-spanning unit of analysis [15] to make sense of the developments in the sector. While taking an ecosystemic perspective, we use business models as the 
theoretical lens to identify and build a conceptual model business ecosystem for connected health by focusing on the value creation and value capture logic of different stakeholders.

In this paper, our focus is to understand the concept of business ecosystem for 'connected health'. We attempt to find answers to the following research questions in this paper:

$R Q$ 1: What could be a potential business ecosystem construct for future connected health?

$R Q$ 2: How could a business ecosystem construct be mapped for the connected health using a business model framework?

Most of the research efforts regarding connected health is concerned with chronic diseases and the global ageing problem $[10,11,16,17]$. However, some studies discuss the impact of connected health on cost efficiency $[18,19]$, especially with regard to preventive medicine [19], the role of pharmacists [16], and patientprofessional electronic communication [20], among others. However, it is not evident how the concept of connected health, often referred to as a health/ lifestyle management model, fits with the healthcare system. Though this paper does not attempt to offer fully generalisable results concerning connected health's overall applicability, we attempt to test its fitness to a different specific use case that will broaden the applicability of connected health: the pediatrics day surgery case. The research case will be further discussed in a forthcoming chapter.

\section{Definitions and prior research}

This chapter outlines the definitions and prior research related to the topic of this paper. We start by discussing the business and innovation ecosystem, continue with a discussion of the Internet of Things (IoT) and serviceoriented architecture (SOA), and end with a discussion on business models in ecosystemic contexts.

\section{Business and innovation ecosystems}

Digital technologies are becoming increasingly intertwined with traditional non-digital products and services $[21,22]$. The concept of 'ecosystems' in businessrelated contexts comes from biological sciences, which, similarly to biological ecosystems, depicts multiple interdependent networks of organisation in a specific context [23].

As digital technology companies began to realise the need to co-evolve for business sustainability, business ecosystems also attracted much attention. The collection of firms that cooperate to produce a holistic and integrated technological system that eventually serves the overall customer set of the intended sector are considered Business Ecosystems [23-27]. One of the earliest authors on business ecosystems, J. F. Moore [28] noted that in the business ecosystem, organisations neither compete, nor cooperate, but rather with the presence of both, co-develop their capabilities around innovations.

Mäkinen \& Dedehayir [23] marks business ecosystems are considered to comprise suppliers, complementors, system integrators, distributors, advertisers, finance providers (VCs, corporate investors, governmental funding agencies, investment banks, and etc.), universities, other research bodies, regulatory authorities, standardisation authorities and customers [29-33]. We acknowledge that participating stakeholders in both business and innovation ecosystems are similar. However, the aim of an innovation ecosystem is usually to innovate for the purpose of improving the sector through innovation and testing.

Innovation is such a business activity that is not on the list of core necessities of every business entity; rather, innovation brings new opportunities and additional competitive advantages. On the contrary, business ecosystems are defined as a collection of firms to produce holistic value for customers through co-evolution [24-26,28]. Innovation can be one of multiple objectives in the case of a business ecosystem. We observe 'innovation ecosystem' to be a slightly separate construct for which the main purpose is to support and foster inno- 
vation. Mäkinen \& Dedehayir [23] adds that business ecosystem and innovation ecosystem as concepts are used interchangeably in management literature. Endogenous and/or exogenous forces usually trigger the emergence of an ecosystem. While business ecosystems in most cases form through endogenous forces, innovation ecosystems often take the other route.

In ecosystems, there are many roles to be played by the participating stakeholders. Some key roles that are discussed in the literature are often titled as: keystone/platform leader/ecosystem leader, niche player/ complementor, wannabe and dominator [23,28,34,35]. The Keystone plays the role of orchestrating the overall ecosystem activities and as a consequence, their decision affects the performance of other stakeholders to some extent, as well as their own. Tiwana et al. [36] highlights designing the overall platform/architecture of the ecosystem as one of the key activities of the keystone by defining the purpose and scope of the ecosystem.

Though Keystone is supposed to be a leader of the network of companies, often it is the case that another participating firm challenges the keystone by supplanting other members of the network through vertical and horizontal integration and thereby becomes more powerful. This type of rivaling firms are dubbed as wannabes. In case a wannabe succeeds in its challenging role, they are also often dubbed dominators [35]. Finally, despite being mostly unnoticed for their direct contribution to the building of the ecosystem and evolution, niche players/complementors represent the biggest population of the ecosystem. Niche players support the keystone in order to create and capture customer value
[23]. Moore [28] states that a keystone firm plays an important role for ecosystem's value creation, value capture and even value sharing within the ecosystem, thus they can attract more complementors to the ecosystem for further participation.

\section{The loT \& service oriented architecture}

The core role of the Internet has changed over the last three decades from the 'Internet of Computers' to the 'Internet of People' and later to the 'Internet of Things' $[14,37]$. Among other potential applications of the loT, healthcare is one of the primary ones [37]. Healthcare has substantially affected the era of Internet with relatively cost-efficient and smart solutions, which are predominantly within eHealth and mHealth domains. With sensor-based innovations and IoT inclusions in the healthcare sector, more incentives are assumed to appear [38,39].

IoT solutions can significantly impact the quality of healthcare services through the availability, accessibility, collection, processing and presentation of meaningful data. Such improvements are possible through monitoring, sensing, communicating, logistics management, diagnosis, recovery, therapy and also administrative tasks $[38,39]$. Though this paper does not deeply discuss technical details of the technology, the serviceoriented architecture of the IOT seems to be a valid conceptual lens. Xu et al. [38] presented a simplified service-oriented architecture (SoA) of the IoT. Figure 1 presents the four-layered SoA.

\begin{tabular}{|c|c|c|c|}
\hline Sensing Layer & $\begin{array}{c}\text { Networking } \\
\text { Layer }\end{array}$ & Service Layer & Interface Layer \\
\hline $\begin{array}{l}\text { RFID } \\
\text { Sensors } \\
\text { Actuators }\end{array}$ & $\begin{array}{l}\text { Basic networking } \\
\text { support \& data } \\
\text { transfer }\end{array}$ & $\begin{array}{l}\text { Creation and } \\
\text { management of } \\
\text { services. }\end{array}$ & $\begin{array}{l}\text { User end Inter- } \\
\text { face }\end{array}$ \\
\hline
\end{tabular}

Figure 1. Four-layered SoA for loT (Adapted from [38]. 
In the first layer of sensing, there is usually physical hardware for data collection. Since the loT is considered to network numerous connected devices, in this layer, those devices sense and collect relevant data. In the second layer, the network layer, the role of connecting all of the 'things' in the network is done. The network layer is also capable of aggregating information from existing IT infrastructures. This is a vital part of the IoT architecture due to the fact that a network is assumed to be enormous and the reliability of the solution needs to be sustainable.

The service layer mostly relies on middleware technologies, which actually provides solutions that an application promises to deliver. Middleware technologies provide the loT infrastructure with a cost-effective platform by reusing hardware and software platforms together. The final layer is called the 'interface layer'. It deals with the user interface of the application. This four-layered, service-oriented architecture will be later used to draw the theoretical framework used for this study.

\section{Business models and ecosystemic contexts}

Business models as a concept came to light during the post-dot-com boom as hype and continued to be a popular term within the ICT industry to explain many different phenomena $[21,40,41]$ including those related to business applications [14]. Most of the business model-related discussions initially evolved around ebusinesses, such firms' value creation logic, and competitive advantage issues [42].

Teece [43] \& Veit et al. [44] highlight substantial impact of the Internet and Internet-related developments on the business model literature due to the emergence of new business opportunities. They also marked the more generalised phenomenon of faster technological advancements being a key for practicing different business models. To that end, during the last decade we have observed academic contributions focusing on different industries. Some examples include: smart power [45], healthcare [14, 46], SMEs [47], ecosystemic contexts $[21,46]$, and the Internet of Things $[13,14,48]$.

In the literature, business models as a conceptual tool are viewed as an architectural [40] system of interdependent activities [49] and an interrelated set of core logic and strategic decision variables $[50,51]$ that explain transaction content, transaction governance and transaction relationship structures for value creation and value capture [52,53]. Reflecting on the above definition of business model, we agree with $\mathrm{Xu}$ et al. [45] and livari [54] that most business model-oriented effort is focused on the firm level and neglect the potential of analysing the interdependence of the growth and success of firms that are evolving in the same business ecosystems. Amit and Zott [52] approach business models as a boundary-spanning new unit of analysis that allows utilisation of the business model concept in the ecosystemic context.

Existing literature identifies value creation and value capture as fundamental to business modeling. It explains how a specific firm or an ecosystem creates value for their customers and in return how the firm/ecosystem captures value for themselves. Business modeling on a firm level seems to be more straightforward compared to an ecosystemic context due to value logic itself. Wirtz et al. [55] provide a 4C Internet business model typology, which fits the contemporary ICTenabled industries. In the $4 \mathrm{C}$ model, Wirtz et al. identify four different business model types where customer value can be created; they are: content, commerce, context and connection.

Combining the $4 \mathrm{C}$ conceptualisation with the previously discussed Service-oriented Architecture (SoA) of the IoT, we conceptualise the value creation and capture logic in an ecosystemic context. On the one hand, this model explains how value is created for end-users from the $4 \mathrm{C}$ perspective. On the other hand, the SoA can explain why end-users will return value to the ecosystem. We illustrate this theoretical conceptualization in figure 2 . 


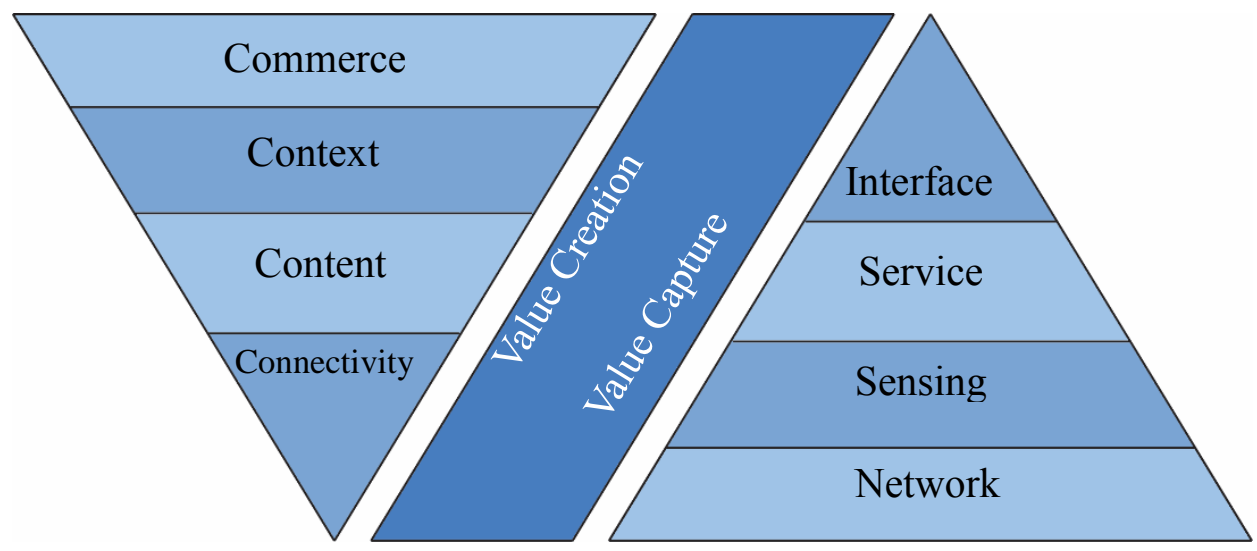

Figure 2. Value creation \& value capture logic: $4 C$-SoA business model perspective for an ecosystemic context.

For the 4C typology, we take a stance similar to Yrjölä et al. [56] and consider these types as being layers which are stacked on top of each other and the lower layers can be considered prerequisite enablers. In ICT-enabled industries, customers first and foremost need connectivity solutions related to the ecosystem. In the next layer, customers should be delivered content services. In the next layer, context, customers should be able to understand the structure of the complex set of solutions and navigate around different solutions with ease and transparency. Finally, in the commerce layer, there can be third-party commercial solutions built on other solutions to offer added-value.

Similarly, we look at the SoA logic from a layered perspective, where the interface layer is the imminent source of value capturing. Next to that is the service layer where different sort of context- and contentoriented middleware services will be created and thus value can be captured. In the sensing layer, there would be different sensor-based devices which collect necessary data for customers, which in turn will generate part of the captured value. Finally, in the network layer, indirect value can be captured for the ecosystem for supplying network and connectivity services.

In explaining the business model value creation and capture logic for the ecosystem, we see an arguable fit between these two perspectives for their matching purposes and also their overlapping characteristics. However, the relationship between these models is likely to be complex. We conceive this initial perspective to be useful in mapping the value creation and value capturing logic in the ecosystemic context and the overall construct of the ecosystem.

\section{Methods}

This study is a part of a research project comprising a wide consortium of business researchers, user experience researchers, health professionals and a large number of companies working together towards an innovation ecosystem for the future-connected health context. This project aims to make a first version of the "Nordic central hospital testlab" that will support companies in the co-creation of services for future hospitals. The first pilot in our research project is service cocreation in the context of pediatric day surgeries.

For this study, the research case is twofold. First, the wider sphere involves understanding the construct of an innovation ecosystem. Second, we approach understanding the innovation ecosystem construct by looking at a pediatric day surgery pilot, specifically how connected health services can affect the processes within in the future. Figure 3 illustrates this twofold case of the study. 


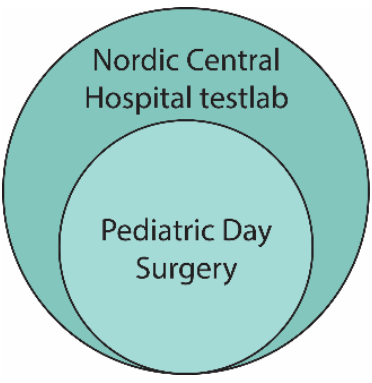

Figure 3. The two-fold case of the study.

Despite having the goal of understanding the construct of an innovation ecosystem for the connected health context, in practice it is complex to define the structure of the ecosystem and the processes of pediatric day surgery. Mason [57] states that to understand a complex setting and retain flexibility and sensitivity to a context that has been less explored before, a qualitative research method would be more suitable.

We apply the concept of business models as a boundary-spanning unit of analysis $[15,52]$ with the $4 \mathrm{C}$-SoA perspective. This research relies on a philosophical standpoint that overlaps between constructivism and critical realism [58,59]. Furthermore, in practice, we apply a qualitative case study for this research where we can collect a rich set of data.

Table 1 summarises the overall data collection for this research between January 2016 and June 2016 in different forms, which is relevant to business models and ecosystem building. Data collection for the study in volved focused/themed meetings with companies, consortium meeting, meeting with project researchers, training and workshop. Altogether, for this research, 27 hours and 50 minutes of activities were recorded which covered business, business model and ecosystemrelated discussion. Since the amount of total discussion hours is quite large for transcription, we summarised the discussions and analysed them. During the course of this study, we met with eight (8) companies individually to discuss their business models and how they can be embedded into a connected health context to offer services that will add value to healthcare.
For the business model-related discussions, the Business Model Wheel [60] was applied to analyse organisational business models. In meetings with project researchers, we initially tested the applicability of the $4 \mathrm{C}$ model and the SoA model as a tool to map different services to understand the ecosystem construct. While service mapping as a term often describes the detailed processes involved in offering specific service [61], in the scope of this research, we opt to use this term to indicate a broader perspective. The map of different services we tend to draw from in this study reflects different needs for services (e.g. needed interface and integration between different services) in future healthcare. Additionally, this map helps to understand the construct of business ecosystem for connected health. Based on the feedback from project researchers, further analysis is conducted.

In parallel with business model and ecosystem-related data collection, we involved different end-user groups in our research (7 doctor interviews, 4 workshops with 4-8 nurses and digital discussions and workshops with 12 parents with ill children. The needs and technology opportunities were clarified with different stakeholder groups focusing on surgery preparations (in the home and at the hospital), surgery itself and the steps that are conducted after the surgery (in the home and at the hospital). During these events with doctors, nurses and patients of ill children, we attempted to uncover healthcare needs for the future where connected health solutions can intervene.

During one-hand discussions with doctors, nurses and parents also helped us initially understand user readiness and technology literacy besides opening up the service needs. On the other hand, through the meetings and workshops with the consortium companies, we could identify potential connected health solutions for a forthcoming pediatric day surgery case. Finally, the internal discussions with project researchers helped us define the boundaries and draw the broad map of services which are feasible for both service providers and end-users. 
Table 1. Business model-related data collection method for the research.

\begin{tabular}{|c|c|c|c|}
\hline Event & Purpose & Duration and date & Respondent remarks \\
\hline Kick-off meeting & $\begin{array}{l}\text { Introduction to the pro- } \\
\text { ject and consortium } \\
\text { participants }\end{array}$ & $\begin{array}{l}4 \text { hours } \\
29.01 .2016\end{array}$ & $\begin{array}{l}\text { All participants in the project } \\
\text { consortium. Includes all compa- } \\
\text { nies, OuluHealth representative. }\end{array}$ \\
\hline $\begin{array}{l}\text { Meeting- Telco operator } \\
\text { company }\end{array}$ & $\begin{array}{l}\text { Understanding BM, role } \\
\text { in ecosystem }\end{array}$ & $\begin{array}{l}1 \text { hour } 15 \text { mins } \\
12.02 .2016\end{array}$ & $\begin{array}{l}\text { Head of programmes, Telecom- } \\
\text { munications operator company. }\end{array}$ \\
\hline $\begin{array}{l}\text { Meeting - HIS provider } \\
\text { company } 1\end{array}$ & $\begin{array}{l}\text { Understanding BM, role } \\
\text { in ecosystem }\end{array}$ & $\begin{array}{l}2 \text { hours } \\
15.02 .2016\end{array}$ & $\begin{array}{l}3 \text { personnel from the Hospital } \\
\text { Information systems provider } \\
\text { company (Top management) }\end{array}$ \\
\hline $\begin{array}{l}\text { Meeting - Network in- } \\
\text { frastructure company }\end{array}$ & $\begin{array}{l}\text { Understanding BM, role } \\
\text { in ecosystem }\end{array}$ & $\begin{array}{l}1 \text { hour } 15 \text { mins } \\
18.02 .2016\end{array}$ & $\begin{array}{l}3 \text { personnel from Network infra- } \\
\text { structure company (Top/middle } \\
\text { level management) }\end{array}$ \\
\hline $\begin{array}{l}\text { Meeting - Telco opera- } \\
\text { tor company }\end{array}$ & $\begin{array}{l}\text { Further discussion of } \\
\text { business models. Futur- } \\
\text { istic discussion }\end{array}$ & $\begin{array}{l}2 \text { hours } \\
25.02 .2016\end{array}$ & $\begin{array}{l}\text { Head of programs, Telecommuni- } \\
\text { cations operator company. }\end{array}$ \\
\hline $\begin{array}{l}\text { Meeting - Global tech- } \\
\text { nology leader (also of- } \\
\text { fers healthcare products) }\end{array}$ & $\begin{array}{l}\text { Understanding BM, role } \\
\text { in ecosystem }\end{array}$ & $\begin{array}{l}1 \text { hour } 10 \text { mins } \\
18.03 .2016\end{array}$ & $\begin{array}{l}\text { Online discussion with } 2 \text { person- } \\
\text { nel }\end{array}$ \\
\hline $\begin{array}{l}\text { Meeting - SME (Major } \\
\text { products: sensors and } \\
\text { sensor based devices) }\end{array}$ & $\begin{array}{l}\text { Understanding BM, role } \\
\text { in ecosystem }\end{array}$ & $\begin{array}{l}1 \text { hour } 40 \text { mins } \\
29.03 .2016\end{array}$ & $\begin{array}{l}2 \text { Personnel including one co- } \\
\text { founder (top management) }\end{array}$ \\
\hline $\begin{array}{l}\text { Meeting- Startup (com- } \\
\text { munication platform for } \\
\text { healthcare) }\end{array}$ & $\begin{array}{l}\text { Understanding BM, role } \\
\text { in ecosystem }\end{array}$ & $\begin{array}{l}1 \text { hour } \\
29.03 .2016\end{array}$ & $\begin{array}{l}\text { Online discussion with one of the } \\
\text { co-founders }\end{array}$ \\
\hline $\begin{array}{l}\text { Meeting - Project Re- } \\
\text { searchers }\end{array}$ & $\begin{array}{l}\text { Ecosystem building po- } \\
\text { tential related discussion }\end{array}$ & $\begin{array}{l}1 \text { hour } 30 \text { mins } \\
08.04 .2016\end{array}$ & $\begin{array}{l}\text { Researchers within the project } \\
\text { focusing on other issues (end- } \\
\text { user, patient journey, etc.) }\end{array}$ \\
\hline $\begin{array}{l}\text { Meeting - Startup (Se- } \\
\text { cure private video con- } \\
\text { ferencing) }\end{array}$ & $\begin{array}{l}\text { Understanding BM, role } \\
\text { in ecosystem }\end{array}$ & $\begin{array}{l}2 \text { hours } \\
28.04 .2016\end{array}$ & $\begin{array}{l}2 \text { personnel from the startup, } \\
\text { including co-founder }\end{array}$ \\
\hline $\begin{array}{l}\text { Meeting - Project Re- } \\
\text { searchers }\end{array}$ & $\begin{array}{l}\text { Ecosystem } \\
\text { initiation }\end{array}$ & $\begin{array}{l}2 \text { hour } 30 \text { mins } \\
03.05 .2016\end{array}$ & $\begin{array}{l}8 \text { researchers altogether com- } \\
\text { menting on ideas for mapping the } \\
\text { ecosystem }\end{array}$ \\
\hline $\begin{array}{l}\text { Meeting - Network in- } \\
\text { frastructure company }\end{array}$ & $\begin{array}{l}\text { Present initial findings } \\
\text { and receive feedback. }\end{array}$ & $\begin{array}{l}2 \text { hours } \\
20.05 .2016\end{array}$ & $\begin{array}{l}4 \text { personnel from the company. } \\
\text { (Top/middle management level). }\end{array}$ \\
\hline $\begin{array}{l}\text { Meeting - HIS provider } \\
\text { company } 2\end{array}$ & $\begin{array}{l}\text { Understanding BM, role } \\
\text { in ecosystem }\end{array}$ & $\begin{array}{l}1 \text { hour } 30 \text { mins } \\
26.05 .2016\end{array}$ & $\begin{array}{l}2 \text { personnel from the top man- } \\
\text { agement of the organisation }\end{array}$ \\
\hline $\begin{array}{l}\text { Meeting - Global tech- } \\
\text { nology leader }\end{array}$ & $\begin{array}{l}\text { Further understanding of } \\
\text { the company's participa- } \\
\text { tion in the ecosystem }\end{array}$ & $\begin{array}{l}2 \text { hours } \\
06.06 .2016\end{array}$ & $\begin{array}{l}1 \text { personnel from the top man- } \\
\text { agement of the organisation in } \\
\text { Finland. }\end{array}$ \\
\hline $\begin{array}{l}\text { Workshop- Overall Pro- } \\
\text { ject Consortium }\end{array}$ & $\begin{array}{l}\text { Present findings, receive } \\
\text { feedback }\end{array}$ & $\begin{array}{l}2 \text { hours } \\
07.06 .2016\end{array}$ & $\begin{array}{l}5 \text { companies' representatives and } \\
\text { all researchers in the project } \\
\text { consortium }\end{array}$ \\
\hline
\end{tabular}




\section{Results}

In this chapter, first, we present some of the vital findings from the discussion with end-user groups (doctors, nurses and parents of ill children) regarding needs of services in future healthcare and about user readiness. Then, we discuss the broad service map for a connected health ecosystem based on our discussion with companies in the project consortium and internal project researchers.

Opinions from the end-user group suggested that given the abundance of health-related data with existing wellness wearables, there should also be some use of these data in healthcare as well. One of the admitted drawbacks of many wellness wearable or apps is that the data is not always clinically valid. However, technological advancements in the health tech sector promise to bring different wearables that will also yield clinical data. For pediatric day surgery, connected health services aiding the process needs integration into hospital information systems in order to automate the preparation processes in the pre-surgery process. Wireless sensor solutions, structured data formats, scoring of patients in the early phases, and automated integration into EPRs would make a big impact on the efficiency of surgical processes. Such low-cognition and automated processes could be useful in pediatrics, geriatrics and other similar cases in which the patient does not have access to online systems and mobile devices, or could not take care of her-/himself.

In pediatrics day surgery, the patient journey comprises four major stages. They are pre-surgery, surgery, postsurgery and rehabilitation. During this patient journey, there are numerous instances where connected health services can intervene to improve the efficiency of services. Such instances start from as early as scheduling an initial appointment for remote observation of patients undergoing rehabilitation. More needs, such as connected health intervention in pediatrics day surgery include direct \& secure communication between doctor/nurse and parents/patients, patient data acquisition, navigation in the hospital, recovery room, patient discharge, patient feedback, etc.
Utilising flexible and wearable devices for vital sign monitoring promote telemonitoring services in rural areas, in addition to promoting patient involvement in self-care, and preventing and tracking illness. The virtual connections and so called virtual hospital services will be more used in the future also, e.g., in pre- and postsurgery phases. It can be used to suggest parents if, for instance, a child develops a risk of an infected wound during rehabilitation.

Although healthcare as a sector is moving towards adapting digital services, the brick-and-mortar healthcare delivery cannot be replaced altogether. One important obstacle that might arise during the implementation of such connected health-enabled healthcare in the future might be resistance to change from a group of end-users. This resistance of change includes adapting to newer technologies while also adapting new processes against established healthcare processes.

Taking our findings from the end-users group (doctors, nurses and parents of ill children) discussions in consideration, we tend to focus on the technology industry to understand the feasibility of identified needs. In order to further understand the construct of a connected health business/innovation ecosystem, findings from end-user discussions were presented to participating companies in the project consortium, who were asked about their initial offering for the case. Depending on their offering for the ecosystem and their business propositions, we coded them using the $4 \mathrm{C}$ and SoA perspectives. In this phase, we observed a fifth layer of firms that are necessary for the case of innovation ecosystems besides the 4 parallel layers discussed in the 4C-SoA framework, the ecosystem layer. In the ecosystem layer, we identify firms which patronise the idea of ecosystem building and also could be or are business ecosystem leaders in their own industry.

Figure 4 portrays the mapping of services needed in the pediatrics day surgery. Building on the $4 \mathrm{C}$-SoA business model perspective for ecosystems, it is observed that value creation and capture logic in the connected health innovation ecosystem context are intertwined with each other. Contemplating deeply, we deduce that 
for connected health innovations, interventions are needed in data collection, data processing, data analysis and healthcare data contextualisation. Thus, we draw two horizontal layers, each containing two separate service types as building blocks. The content service layer comprises virtual context services and contentprocessing services. Similarly, the physical context layer comprises interface services and sensing services. Additionally, we identify two vertical layers, which are the ecosystem layer and the connectivity/networking layer.

Connectivity/networking layer companies provide connectivity for the medical devices and sensors. While the ecosystem layer companies promote, facilitate and patronise the idea of ecosystem building and maintenance. The network/connectivity layer aggregates existing IT infrastructures, and it is the base for the loT architecture. The difference between these vertical layers and horizontal layer is that the business models in these vertical layers are not necessarily directly related to the connected health business context, but they facilitate connected health businesses. Also, these vertical layers ideally serve ecosystemic value to both the horizontal layers by providing connectivity and ecosystem facilitation.
The two horizontal layers constitute actual connected health services that can improve healthcare efficiency in the future. The idea of connected health is built on individual's health related data, and efficient utilization of that data through reliable services; these two layers deal specifically with that. The physical context layer comprises business models that sense data directly from physical premises where healthcare is provided, such as: hospital premises, the individual's home and an ambulance. Similarly, there are services where the system needs end-users' (patient/doctor/nurse) direct participation for data collection through service interfaces. Interface services also allow human participants to communicate in an organised manner. The content service layer is considered a high-level system layer composed of IoT applications and middleware systems besides healthcare data contextualisation services. In this layer service providers utilise the data combining hardware and software solutions for archiving, processing, and analysing the data. The service layer relies on cost-effective service platforms, using mostly middleware technologies.

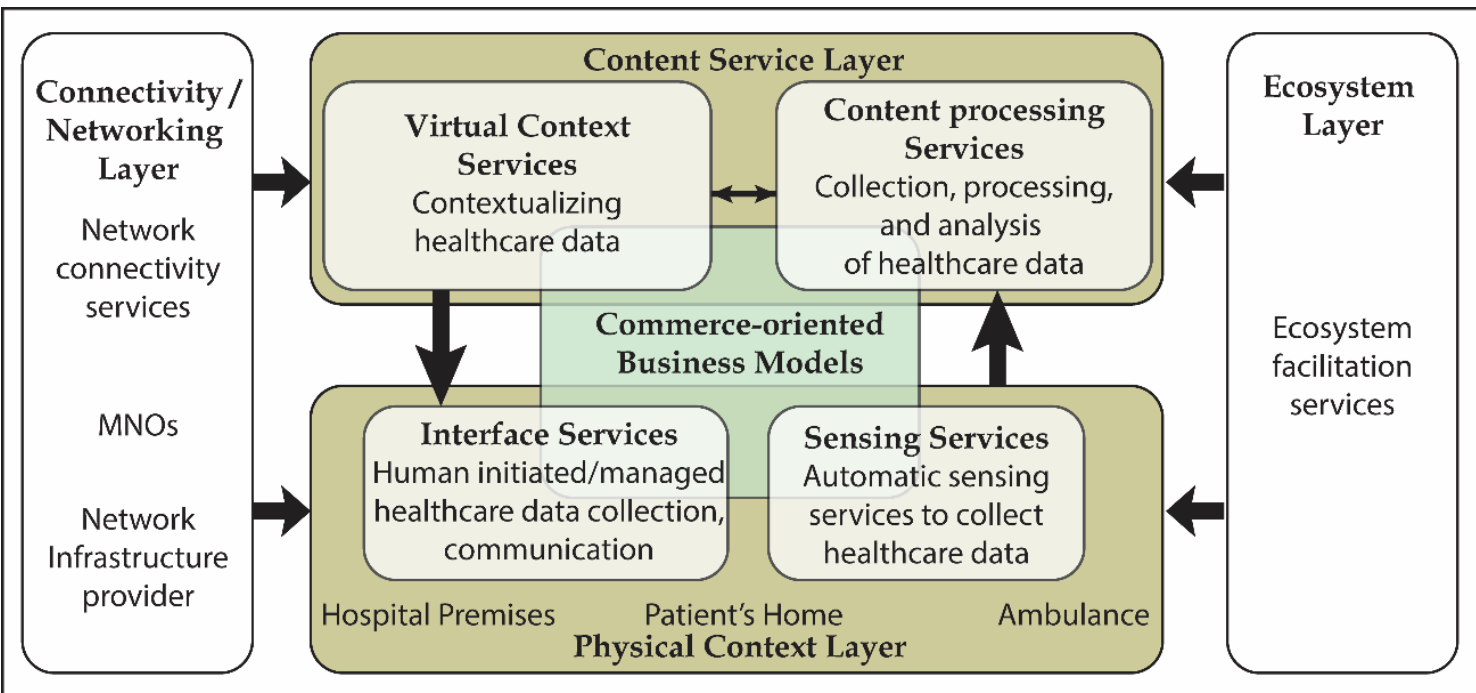

Figure 4. Service map for the connected health business ecosystem- Nordic central hospital test lab. 
If we look at the physical context layer in the case of pediatric day surgeries, sensors are used to collect and monitor vital signs, that is, patient data. The new concept of wearable, non-invasive vital sign sensors is introduced in medical monitoring and well-being applications. The ideal design for wearable monitoring devices is to use flexible substrates, i.e., printed electronics and advanced materials combined with low-power electronics, IC circuits and IoT. Flexible monitoring devices can be embedded into clothing to monitor human vital signs such as body temperature, heart rate, blood pressure, pulse oxygenation, and blood glucose. Interface services offer solutions for end-users. End-user applications retrieve analysed data from databases to view health/healthcare information.

It is important to point out that in the content service layer, there is a need to offer combined service applications for end-users. Such combined service applications would manage healthcare data contextualisation via efficient data processing services. We cannot expect that the parents and children are downloading new applications during each phase of the pediatric surgery case. In connected health, contents can vary from vital healthcare data, such as an individual's health history, to communication between individual and health professionals (text, audio and video).

Furthermore, we observe the possibility of building commerce-oriented business models for connected health, harnessing the potential of the Physical Context Layer and the Content Service Layer. We also attempt to define the value flow from these different layers to conceptualise how and why this can work in practice. We attempt to show the relatedness of each layer in the ecosystem by connecting them with arrows. Furthermore, Table 2 summarises our understanding with regard to the value flows within the ecosystem.

Table 2. Value flow map between different layers of the ecosystem.

\begin{tabular}{|c|c|c|c|c|}
\hline \multicolumn{2}{|c|}{$\begin{array}{l}\text { Layer from where } \\
\text { value is generated }\end{array}$} & Value offering & $\begin{array}{l}\text { Layer the value } \\
\text { is offered to }\end{array}$ & Needs in the case of pediatric surgery \\
\hline \multicolumn{2}{|c|}{ Connectivity layer } & $\begin{array}{l}\text { Mobile network connectivity } \\
\text { and network infrastructure } \\
\text { related value }\end{array}$ & $\begin{array}{l}\text { Content service } \\
\text { layer, Physical } \\
\text { context layer }\end{array}$ & $\begin{array}{l}\text { network needs to work safely in all phases in } \\
\text { the home and hospital. It is needed to transfer } \\
\text { and use wireless sensor data, virtual connec- } \\
\text { tivity and to run different devices in OT. }\end{array}$ \\
\hline \multirow[t]{2}{*}{$\begin{array}{l}\text { Content } \\
\text { service } \\
\text { layer }\end{array}$} & $\begin{array}{l}\text { Content } \\
\text { processing } \\
\text { layer }\end{array}$ & $\begin{array}{l}\text { Accumulates all health- } \\
\text { related data and process it for } \\
\text { further contextualising }\end{array}$ & $\begin{array}{l}\text { Virtual context } \\
\text { layer }\end{array}$ & $\begin{array}{l}\text { Connected health service integration into } \\
\text { hospital information systems in order to au- } \\
\text { tomate the preparation processes in the pre- } \\
\text { surgery and post-surgery process, including } \\
\text { communication activities. }\end{array}$ \\
\hline & $\begin{array}{l}\text { virtual } \\
\text { context } \\
\text { layer }\end{array}$ & $\begin{array}{l}\text { Contextualise health related } \\
\text { data received from other } \\
\text { layers and also manage all } \\
\text { context-type of connected } \\
\text { health services. }\end{array}$ & $\begin{array}{l}\text { Interface layer, } \\
\text { Content pro- } \\
\text { cessing layer }\end{array}$ & $\begin{array}{l}\text { Wireless sensor solutions, structured data } \\
\text { formats, and automated integration into EPRs } \\
\text { would have a big impact on the efficiency of } \\
\text { surgical processes. }\end{array}$ \\
\hline \multirow[t]{2}{*}{$\begin{array}{l}\text { Physical } \\
\text { context } \\
\text { layer }\end{array}$} & $\begin{array}{l}\text { Interface } \\
\text { layer }\end{array}$ & $\begin{array}{l}\text { Health related data (text, } \\
\text { audio, video) collected from } \\
\text { human-initiated sources }\end{array}$ & $\begin{array}{l}\text { Content pro- } \\
\text { cessing layer }\end{array}$ & $\begin{array}{l}\text { Text-based and video solutions will be more } \\
\text { used to offer 'virtual doctor services' in the } \\
\text { future, e.g., to clarify the wound situations } \\
\text { after the surgery. }\end{array}$ \\
\hline & $\begin{array}{l}\text { Sensing } \\
\text { layer }\end{array}$ & $\begin{array}{l}\text { Health-related data collected } \\
\text { from sensor-based wireless } \\
\text { devices }\end{array}$ & $\begin{array}{l}\text { Content pro- } \\
\text { cessing layer }\end{array}$ & $\begin{array}{l}\text { wireless sensors such as body temperature, } \\
\text { heart rate, blood pressure, pulse oxygenation, } \\
\text { and blood glucose, sensor integration into the } \\
\text { wearables, e.g., hospital clothes or beds }\end{array}$ \\
\hline \multicolumn{2}{|c|}{ Ecosystem layer } & $\begin{array}{l}\text { Ecosystem building support, } \\
\text { interface support, broader } \\
\text { business network }\end{array}$ & $\begin{array}{l}\text { Content service } \\
\text { layer, Physical } \\
\text { context layer }\end{array}$ & $\begin{array}{l}\text { All the solutions should be offered as one } \\
\text { service for the end-user, not the way that the } \\
\text { app should be downloaded in the different } \\
\text { phases of the pediatric surgery process }\end{array}$ \\
\hline
\end{tabular}


In Figure 4, we display a service map for the connected health business/innovation ecosystem - a Nordic central hospital test lab. While identifying different techaided services that will be needed in future healthcare, there is a need for technological readiness from service providers. In the current market situation, such connected health solutions are emerging to positively impact and improve efficiency in healthcare. However, there is room for significant improvement and value addition through other services. With an ecosystemic approach, connected health startups and SMEs offer services faster and with reliable service quality, hence faster growth for the overall sector.

The Nordic central hospital test lab offers product testing, feasibility testing and coaching. However, we consider it an innovation ecosystem due to its relationships with additional stakeholders ranging from global corporations, national healthcare organisations, SMEs, University hospitals, other hospitals to extend and cocreate offers from the startups and SMEs. It is arguable that the biggest value of such an innovation ecosystem is to offer a bigger picture to incoming startups and service innovators. Additionally, such innovation ecosystems can foster the advancement of the healthcare sector via co-creation activities in an ecosystemic setting. Connected health is an emerging context and we believe that a holistic support programme for newborn startups is going to foster further business ecosystem building.

\section{Discussion \& conclusions}

Connected health as a concept is perceived to be a model of health/ lifestyle management in earlier research, while we see that connected health services are moving forward to serve as an important element in the healthcare sector through data and information aggregation, processing and proper dissemination. Connected health as a research focus had so far been targeted for issues like global ageing population and chronic diseases [10, 11, 16, 17]. In this study, we approached the issue of connected health from a different angle of pediatrics day surgery, which broadens the scope of this emerging concept. Additionally, there is a need to uti- lise the ecosystemic perspective in understanding the health/healthcare-related businesses $[13,14]$, how an ecosystem grows and what their benefits are. Building upon an innovation ecosystem perspective, our study introduces a new research avenue.

This paper outlines the need for innovation ecosystems in order to have high-functioning business ecosystems in the future for health and healthcare-related businesses. Healthcare being a very sensitive service sector, it is of the utmost importance that the users are given the highest priority while designing new services. Also, unlike many other profit-oriented industries, the overall value created by service providers in the healthcare sector needs to constantly assure uncompromised service quality with clinical accuracy while capturing substantial economic value for the business entities.

The Nordic central hospital test lab as a case is striving to build an innovation ecosystem. On the one hand, ecosystem-layer companies can benefit from coopetition model in such innovation ecosystems while also encouraging new companies to participate in their own business ecosystems, which in turn results in business sustainability. On the other hand, for incoming startups, this type of innovation ecosystem offers facilitation services ranging from business guidance, product testing, access to a broad network of companies as well as access to new markets for business. In our observation, an exogenous construction of an innovation ecosystem is a proactive step towards a successful business ecosystem building for the connected health context.

In responding to the research questions, we mapped the services needed through connected health solutions to understand the business/innovation ecosystem of the Nordic central hospital test lab utilising a broad literature base and thorough empirical analysis. Though the broad service map that we present in this paper was intended for building an innovation ecosystem, we perceive it to be generalisable for constructing business ecosystems in connected health contexts as well. The new business ecosystems will eventually be headed by business entities such as 'keystones', whereas in this case the Nordic central hospital test lab will play the role for the orchestration of ecosystems. The rise of 
dominators or wannabes in these kinds of innovation ecosystems are less likely because of a common interest in innovation and nurturing startups and SMEs mostly for the new healthcare-related service creation. However, one key difference that can be observed for this case is that niche players or contributors are bigger companies who aim to build their own business ecosystems. It is imperative that a lot of startups who are coming for testing and building will move out of the innovation ecosystem to other business ecosystems. Since this is one of the key aims of innovation ecosystems like the Nordic central hospital test lab, orchestrators need to continuously look for new startups/SMEs in the pipeline to keep up the ecosystem.

The literature covered in the study involves understanding the phenomenon of connected health, understanding the meaning of business and innovation ecosystems, the service-oriented architecture of the loT as well as the business model perspective. Additionally, the empirical dataset gathered during this research allowed us to apply our theoretical learning. Figure 4 and Table 2 summarise our answers to Research Question 1 by explaining the service map and value flow from a constructionist viewpoint.

With regard to the second research question, business and innovation ecosystems are very complex and mapping them is challenging because of the number of stakeholders involved in an ecosystem. However, acknowledging the fact that broad mapping of services to understand the ecosystem construct has the inherent risk of missing some detail of the overall ecosystem, we propose the two-way mapping of an ecosystem. First, the ecosystem construct should be understood. That is, we need to logically organise the key services needed in the ecosystem to be able to create significant value. Second, in order to test the feasibility of the ecosystem construct, it is required to check the value flow between different services, hence service providers.

This paper contributes to the literature in multiple ways. First, we discuss a new problem, pediatric day surgery, from the perspective of connected health. Second, this paper provides a new angle for ecosystem building in connected health context by broadly map- ping the services needed. Third, we combine business model literature with loT literature to provide a conceptual framework to understand ecosystems by service mapping in ICT contexts. In sum, our theoretical contribution touches the boundaries of business model literature, IoT literature, business/innovation ecosystem literature as well as connected health literature.

This paper offers interesting insights for managerial entities as well, let it be business management or hospital management. Our mapping can help to approach connected health ecosystem building. Also, beyond the context of connected health, such broad service mapping concepts can be applied to ecosystem building in other industrial contexts.

We anchored our study in a broad range of literature to manage the issue of connected health that has not been approached from an ecosystemic perspective. Thus, we had to manage a broad range of literature from multiple disciplines, but we lacked academic literature upon which we could build. Additionally, the strategy of non-transcription might have implications for the validity of the research. To address this problem, summaries were shared with participants or reflection meetings were organised to remove misinterpretations.

In this article the view of connected health business ecosystem was analysed from the perspective of industrial offerings and their interfaces based on the service needs identified from end user groups (doctors, nurses and parents of ill children). This will help companies to build services that easier to use health professionals and patients. In the future research, the natural next step for this research is to study how an end user (health professional, patient, caregiver) get added value of developed services. From the pediatrics day surgery perspective, we would like to present the patient journey path in more detail as a continuation of this research. Additionally, we would like to combine our understanding of the business/innovation ecosystem construct and end-user group feedback towards a business model for the ecosystem. 


\section{Conflict of interest}

The authors declare that there are no conflicts of interest.

\section{References}

[1] Häyrinen K. The health, social services and regional government reform is above all a change of practices by means of digitalization. Finnish Journal of eHealth and eWelfare 2016;8(4):146.

[2] FinJeHew / News. The latest Kanta service is ready. Kelain can now be used to issue electronic prescriptions Finnish Journal of eHealth and eWelfare 2016;8(4):148.

[3] Oh H, Rizo C, Enkin M, Jadad A. What is eHealth?: a systematic review of published definitions. World Hosp Health Serv. 2005 Jan;41(1):32-40. https://doi.org/10.2196/jmir.7.1.e1

[4] Pagliari C, Sloan D, Gregor P, Sullivan F, Detmer D, Kahan JP, Oortwijn W, MacGillivray S. What is eHealth (4): a scoping exercise to map the field. J Med Internet Res. $2005 \quad$ Mar 31;7(1):e9. https://doi.org/10.2196/jmir.7.1.e9

[5] Gomes J, Ahokangas P and Moqaddamerad S, "Business modeling options for distributed network functions virtualization: Operator perspective," in Conference Proceedings from European Wireless 2016. pp. 37.

[6] Martikainen S, Korpela M, Luukkonen I, Vainikainen V. Where does the interaction break down? The stakeholder map of health IT systems development and use in Finland. Finnish Journal of eHealth and eWelfare 2015;7(4):192-209.

[7] Iglehart JK. Connected health: Emerging disruptive technologies. Health Aff 2014 Feb;33(2):190. https://doi.org/10.1377/hlthaff.2014.0042

[8] UCD Connected health. What is Connected health? Ireland: UCD Connected health; 2016. Available at: http://www.connectedhealthireland.com/what-isconnected-health/ [cited 17 mar. 2017].

[9] Ahokangas P, Perälä-Heape $M$, Jämsä T. Alternative futures for individualized connected health. In: Gurtner
S, Soyez K (eds). Challenges and opportunities in health care management. Switzerland: Springer International Publishing; $2015 . \quad$ pp. 61-74. https://doi.org/10.1007/978-3-319-12178-9_5

[10] Galbraith B, Mulvenna M, McAdam R, Martin S. Open innovation in connected health: an empirical study and research agenda. InConference on Open Innovation: Creating Products and Services through Collaboration (ISPIM-2008) in Tours, France 2008.

[11] Caulfield BM, Donnelly SC. What is Connected Health and why will it change your practice? QJM. 2013 Aug 1;106(8):703-707. https://doi.org/10.1093/qjmed/hct114

[12] Pitkänen J, Pitkäranta M. Improving meaningful use and user experience of healthcare information systems towards better clinical outcomes. Finnish Journal of eHealth and eWelfare 2016;8(2-3):98-106.

[13] Pang Z, Zheng L, Tian J, Kao-Walter S, Dubrova E, Chen $Q$. Design of a terminal solution for integration of in-home health care devices and services towards the Internet-of-Things. Enterprise Information Systems. 2015 Jan 2;9(1):86-116. https://doi.org/10.1080/17517575.2013.776118

[14] Gomes J, Moqaddemerad S. Futures Business Models for an IoT Enabled Healthcare Sector: A Causal Layered Analysis Perspective. Journal of Business Models. 2016 Oct 23;4(2).

[15] Zott C, Amit R, Massa L. The business model: recent developments and future research. Long Range Planning 2011;37(4):1019-1042. https://doi.org/10.1177/0149206311406265

[16] Barr PJ, McElnay JC, Hughes CM. Connected health care: the future of health care and the role of the pharmacist. J Eval Clin Pract. 2012 Feb;18(1):56-62. https://doi.org/10.1111/j.1365-2753.2010.01522.x

[17] Christensen K, Doblhammer G, Rau R, Vaupel JW. Ageing populations: the challenges ahead. Lancet. 2009 Oct 3;374(9696):1196-208. https://doi.org/10.1016/S0140-6736(09)61460-4

[18] Wilson SR, Cram P. Another Sobering Result for Home Telehealth - and Where We Might Go Next: 
Comment on "A Randomized Controlled Trial of Telemonitoring in Older Adults With Multiple Health Issues to Prevent Hospitalizations and Emergency Department Visits". Arch Intern Med 2012 May 28;172(10):779-80. https://doi.org/10.1001/archinternmed.2012.685

[19] Agboola SO, Ball M, Kvedar JC, Jethwani K. The future of Connected Health in preventive medicine. QJM. $2013 \quad$ Sep;106(9):791-794 https://doi.org/10.1093/qjmed/hct088

[20] Niemi A, Hupli M, Koivunen M. The use of electronic communication for patient-professional interactionnursing staff's point of view. Finnish Journal of eHealth and eWelfare. 2016 Dec 9;8(4):200-15.

[21] livari MM, Ahokangas $P$, Komi M, Tihinen M, Valtanen K. Toward ecosystemic business models in the context of industrial internet. J. Bus. Models. 2016 Oct 23;4(2):42-59. https://doi.org/10.2307/41165799

[22] Turber S, Smiela C. A business model type for the internet of things. Conference paper. 22nd European Conference on Information Systems (ECIS 2014), Tel Aviv, Israel.

[23] Mäkinen SJ, Dedehayir O. Business ecosystem evolution and strategic considerations: A literature review. In: Engineering, Technology and Innovation (ICE), 2012 18th International ICE Conference on 2012 Jun 18 (pp. 1-10).

[24] Bahrami H, Evans S. Flexible recycling and hightechnology entrepreneurship. California Management Review. 1995 Apr 1;37(3):62-89.

[25] Basole RC. Visualization of interfirm relations in a converging mobile ecosystem. Journal of information Technology. 2009 Jun 1;24(2):144-159. https://doi.org/10.1057/jit.2008.34

[26] Lusch RF. Reframing supply chain management: a service-dominant logic perspective. Journal of Supply Chain Management. 2011 Jan 1;47(1):14-18 https://doi.org/10.1111/j.1745-493X.2010.03211.x

[27] Ågerfalk PJ, Fitzgerald B. Outsourcing to an unknown workforce: Exploring opensurcing as a global sourcing strategy. MIS quarterly. 2008 Jun 1:385-409.
[28] Moore JF. Predators and prey: a new ecology of competition. Harvard business review. 1993 May $1 ; 71(3): 75-83$.

[29] Li YR. The technological roadmap of Cisco's business ecosystem. Technovation. 2009 May 31;29(5):37986. https://doi.org/10.1016/j.technovation.2009.01.007

[30] Adner R, Kapoor R. Value creation in innovation ecosystems: How the structure of technological interdependence affects firm performance in new technology generations. Strategic management journal. 2010 Mar 1;31(3):306-33. https://doi.org/10.1002/smj.821

[31] Iyer B, Davenport TH. Reverse Engineering: Google's Innovation Machine. Harvard Business Review. 2008;86(4).

[32] Meyer AD, Gaba V, Colwell KA. Organizing far from equilibrium: Nonlinear change in organizational fields. Organization Science. 2005 Oct;16(5):456-73. https://doi.org/10.1287/orsc.1050.0135

[33] Whitley EA, Darking M. Object lessons and invisible technologies. Journal of information technology. 2006 Sep 1;21(3):176-84.

https://doi.org/10.1057/palgrave.jit.2000065

[34] Iansiti M, Levien R. Strategy as ecology. Harvard business review. 2004 Mar 1;82(3):68-81.

[35] Cusumano MA, Gawer A. The elements of platform leadership. MIT Sloan Management Review. 2002 Apr $1 ; 43(3): 51$.

[36] Tiwana A, Konsynski B, Bush AA. Research commentary-Platform evolution: Coevolution of platform architecture, governance, and environmental dynamics. Information Systems Research. 2010 Dec;21(4):675-87. https://doi.org/10.1287/isre.1100.0323

[37] Coetzee L, Eksteen J. The Internet of Thingspromise for the future? An introduction. InIST-Africa Conference Proceedings, 20112011 May 11 (pp. 1-9).

[38] Xu Da L, He W, Li S. Internet of things in industries: A survey. IEEE Transactions on industrial informatics. $2014 \quad$ Nov;10(4):2233-43. https://doi.org/10.1109/TII.2014.2300753 
[39] Domingo MC. An overview of the Internet of Things for people with disabilities. Journal of Network and Computer Applications. 2012 Mar 31;35(2):584-96. https://doi.org/10.1016/j.jnca.2011.10.015

[40] Timmers P. Business models for electronic markets. Electronic markets. 1998 Jan 1;8(2):3-8. https://doi.org/10.1080/10196789800000016

[41] Onetti A, Zucchella A, Jones MV, McDougall-Covin PP. Internationalization, innovation and entrepreneurship: business models for new technology-based firms. Journal of Management \& Governance. 2012 Aug 1;16(3):337-68. https://doi.org/10.1007/s10997-0109154-1

[42] Wirtz BW, Pistoia A, Ullrich S, Göttel V. Business models: Origin, development and future research perspectives. Long Range Planning. 2016 Feb 29;49(1):3654. https://doi.org/10.1016/j.Irp.2015.04.001

[43] Teece DJ. Business models, business strategy and innovation. Long range planning. 2010 Jun 30;43(2):172-94.

https://doi.org/10.1016/j.Irp.2009.07.003

[44] Veit D, Clemons E, Benlian A, Buxmann P, Hess T, Kundisch D, Leimeister J, Loos P, Spann M. Business Models: An Information Systems Research Agenda. Business \& Information Systems Engineering. 2014, Vol 6, No.1, pp. Available at: http://aisel.aisnet.org/bise/vol6/iss1/8/

[45] Xu Y, Kopsakangas-Savolainen M, Ahokangas P, Li F. Ecosystemic business model and value in the peer-topeer smart grid. The proceedings of 2016 Global Energy Interconnection. 2016:858-71.

[46] Jansson N, Ahokangas $P$, livari $M$, Perälä-Heape $M$, Salo S. The Competitive Advantage of an Ecosystemic Business Model: The Case of OuluHealth. Interdisciplinary Studies Journal. 2014 Jan 1;3(4):282.

[47] livari MM. Dynamics of Openness in SMEs: A Business Model and Innovation Strategy Perspective. Journal of Business Models. 2015 Nov 17;3(2).

[48] Westerlund M, Leminen S, Rajahonka M. Designing business models for the internet of things. Technology Innovation Management Review. 2014 Jul 1;4(7):5.
[49] Zott C, Amit R. Business model design: an activity system perspective. Long range planning. 2010 Jun 30;43(2):216-26. https://doi.org/10.1016/j.Irp.2009.07.004

[50] Morris M, Schindehutte M, Allen J. The entrepreneur's business model: toward a unified perspective. Journal of business research. 2005 Jun 30;58(6):726-35. https://doi.org/10.1016/j.jbusres.2003.11.001

[51] Shafer SM, Smith HJ, Linder JC. The power of business models. Business horizons. 2005 Jun 30;48(3):199207. https://doi.org/10.1016/j.bushor.2004.10.014

[52] Amit R, Zott C. Value creation in e-business. Strategic management journal. 2001 Jun 1;22(6-7):493-520. https://doi.org/10.1002/smj.187

[53] Weill P, Vitale M. What IT infrastructure capabilities are needed to implement e-business models?. Mis Quarterly. 2002 Mar 1;1(1):17.

[54] livari M. Exploring business models in ecosystemic contexts. PhD Thesis. Acta Universitatis Ouluensis. G, Oeconomica. Oulu, Finland: University of Oulu; 2016.

[55] Wirtz BW, Schilke O, Ullrich S. Strategic development of business models: implications of the Web 2.0 for creating value on the internet. Long range planning. $2010 \quad$ Jun 30;43(2):272-90. https://doi.org/10.1016/j.Irp.2010.01.005

[56] Yrjölä S, Ahokangas P, Matinmikko M. Evaluation of recent spectrum sharing concepts from business model scalability point of view. InDynamic Spectrum Access Networks (DySPAN), 2015 IEEE International Symposium on 2015 Sep 29 (pp. 241-250).

[57] Mason J. Qualitative researching. Sage Publications Ltd; 2002 Aug 29. 224 p.

[58] Kwan KM, Tsang EW. Realism and constructivism in strategy research: A critical realist response to Mir and Watson. Strategic Management Journal. 2001 Dec 1;22(12):1163-1168. https://doi.org/10.1002/smj.199

[59] Peters LD, Pressey AD, Vanharanta M, Johnston WJ. Constructivism and critical realism as alternative approaches to the study of business networks: Convergences and divergences in theory and in research practice. Industrial Marketing Management. 2013 Apr 
30;42(3):336-46.

https://doi.org/10.1016/j.indmarman.2013.02.003

[60] Ahokangas P, Juntunen M, Myllykoski J. Cloud computing and transformation of international ebusiness models. In: A Focused Issue on Building New Competences in Dynamic Environments. Emerald Group
Publishing Limited; 2014 pp. 3-28. https://doi.org/10.1108/S1744-211720140000007001

[61] Getz D, O’Neill M, Carlsen J. Service quality evaluation at events through service mapping. Journal of travel research. 2001 May;39(4):380-390. https://doi.org/10.1177/004728750103900404 